\title{
Post-entry performance of international new ventures: the mediating role of learning orientation
}

Article

Accepted Version

Gerschewski, S., Lew, Y. K., Khan, Z. and Park, B. I. (2018) Post-entry performance of international new ventures: the mediating role of learning orientation. International Small Business Journal, 36 (7). pp. 807-828. ISSN 1741-2870 doi: https://doi.org/10.1177/0266242618790321 Available at https://centaur.reading.ac.uk/79540/

It is advisable to refer to the publisher's version if you intend to cite from the work. See Guidance on citing.

To link to this article DOI: http://dx.doi.org/10.1177/0266242618790321

Publisher: Sage

All outputs in CentAUR are protected by Intellectual Property Rights law, including copyright law. Copyright and IPR is retained by the creators or other copyright holders. Terms and conditions for use of this material are defined in the End User Agreement.

www.reading.ac.uk/centaur 
Central Archive at the University of Reading

Reading's research outputs online 


\section{Post-Entry Performance of International New Ventures: The Mediating Role of Learning Orientation}

Stephan Gerschewski ${ }^{\text {a, }}$, Yong Kyu Lew ${ }^{\text {b, }}$, Zaheer Khan ${ }^{\text {c, } 2}$, Byung Il Park b, 3

${ }^{a}$ Henley Business School, University of Reading, Whiteknights, Reading, RG5 4UW, United Kingdom

${ }^{b}$ Hankuk University of Foreign Studies, College of Business, 107, Imun-ro, Dongdaemungu, Seoul, 02451, Republic of Korea

${ }^{c}$ University of Kent, Kent Business School, Sibson, Parkwood Road, Canterbury, Kent, CT2 7FS, United Kingdom

Acknowledgements: This work was partially supported by Hankuk University of Foreign Studies Research Funds.

* Corresponding author. Tel.: +44 (0)118 3787176.

E-mail addresses: s.gerschewski@henley.ac.uk (S. Gerschewski), yklew@hufs.ac.kr (Y.K. Lew), z.khan-53@kent.ac.uk (Z. Khan), leedspark@hufs.ac.kr (B.I. Park)

${ }^{1}$ Tel.: +82 (0)2 21738823 .

2 Tel.: +44 (0)1227 827405 .

${ }^{3}$ Tel.: +82(0)2 21733193 . 


\title{
Post-Entry Performance of International New Ventures: The Mediating Role of Learning Orientation
}

\begin{abstract}
This paper investigates the role of learning orientation in the post-entry performance of international new ventures (INVs) by examining the relationships of niche strategy, network resources, and learning orientation with the multi-dimensional post-entry performance of INVs. Based on the INV internationalisation literature, we develop and validate a conceptual model, using a sample of 147 INVs from the two relatively small and open economies of New Zealand and Australia. The results show that the learning orientation of INVs positively mediates the relationship between niche orientation and network resources and INVs' post-entry performance. Our study indicates that learning orientation may be an important capability through which INVs' focused international business (IB) strategies and resources (e.g., niche orientation and network resources) may influence their multi-dimensional post-entry performance in terms of operational, financial, and overall effectiveness measures. We draw key implications for research on INVs' post-entry behaviour by explicating the role played by the firms' learning capabilities, and how these capabilities may interact with their strategies and resources in enhancing the post-entry performance of INVs.
\end{abstract}

Keywords: international new venture, learning orientation, niche orientation, network resources, post-entry performance 


\section{INTRODUCTION}

The emergence of early and rapidly internationalising firms has become an increasingly relevant feature in the international business (IB) landscape, primarily since the early 1990s (Knight and Cavusgil, 1996; Jones, Coviello, \& Tang, 2011). These entrepreneurial companies are often small and medium-sized, and are typically characterised by their innovative nature and global mindset, thus viewing the entire world rather than merely their domestic market as their marketplace. There has been a growing interest in better understanding the internationalisation behaviour of international new ventures (INVs) (Oviatt and McDougall, 1994; Knight and Cavusgil, 1996; Jones et al., 2011; Baum, Schwens, \& Kabst, 2011; Cavusgil and Knight, 2015; Zander, McDougall-Covin, \& Rose, 2015). These studies have greatly enhanced our knowledge of INVs and their development, often leading to their becoming key global players. Despite the contributions of existing studies, relatively limited research has focused on the post-entry trajectory of INVs (e.g., Mudambi and Zahra, 2007; Jones et al., 2011; Morgan-Thomas and Jones, 2009; Sui and Baum, 2014; Gerschewski, Rose, \& Lindsay, 2015; Khan and Lew, 2018).

Anecdotal evidence points to the relatively low rates of survival and short longevity of INVs after their initial internationalisation activities (e.g., Kuivalainen, Saarenketo, \& Puumalainen, 2012; Mudambi and Zahra, 2007; Sui and Baum, 2014). For instance, Mudambi and Zahra (2007: 342) note that INVs may have failure rates of $41 \%$ compared to $26 \%$ for those firms that adopted a more sequential entry mode. Similarly, Kuivalainen et al. (2012) reported that $68 \%$ in their sample were born global firms, but most of them were not successful in international markets.

Studies also note that capabilities and network relationships as a key resource can play an important role in shaping firms' internationalisation behaviours (Coviello, 2006; 
Jones et al., 2011). However, relatively few studies have focused on gaining a better understanding of the key resources, business strategies and capabilities, which may, in turn, explain the post-entry performance of INVs (e.g., Jones et al., 2011; Kuivalainen, Sundqvist, \& Servais, 2007; Gerschewski et al., 2015; Fernhaber and Li, 2013). The existing literature often highlights the vital role of INVs' network relationships in their rapid rise; however, the mechanisms through which network relationships may improve these firms' post-entry performance and development are generally not well known (Fernhaber and Li, 2013). In this context, Coviello (2015: 22) called for further research into the role of knowledge, learning, and capabilities, noting that "one might leverage extant IE [International Entrepreneurship] (and other) research to more clearly disentangle and then understand the relationships between knowledge, learning, capabilities, strategy and performance in INVs". Firms may often gain valuable knowledge and improve performance through network relationships. As a result, network relationships can serve as a key resource for firms to tap into developing a sustainable competitive advantage (e.g., Gulati, 1999; Inkpen and Tsang, 2005; Lew, Sinkovics, \& Kuivalainen, 2013).

In this study, we are responding to Coviello's (2015) call for future research into INVs. Our point of departure is the underappreciation of the key mechanisms and capabilities that may be central to INVs' differential post-entry performance, and through which network relationships can potentially enhance their firms' post-entry performance (Fernhaber and Li, 2013).

We generally lack an in-depth understanding about 1) how INVs utilise different resources through network relationships, business strategies, and capabilities, and 2) how and to what extent they altogether may lead to their post-entry performance over time. A few studies have highlighted the role of niche orientation and network relationships in the 
internationalisation and performance of INVs; however, the mechanisms and processes through which these may affect the post-entry performance of INVs are generally not well-known (e.g., Knight and Liesch, 2015).

This paper contributes to the extant literature on INVs in several ways. First, our research brings the key role of learning into the domain of INVs' post-entry performance. In doing so, we examine the effects of the inter-relationships between a focused business strategy (i.e., niche orientation), resource (i.e., network resources) and capability (i.e., learning orientation), which may be central to explaining the multi-dimensional postentry performance of INVs. Second, our paper introduces the notion of learning orientation as a mediator in explicating the factors that may drive the post-entry performance of INVs. Third, our empirical results suggest that learning orientation may be an important 'capability' through which INVs' network resources and niche strategy may affect their multi-dimensional post-entry performance, in terms of operational, financial, and overall effectiveness measures.

\section{THEORY AND HYPOTHESIS DEVELOPMENT}

\section{Learning in the INVs' internationalisation process}

In terms of the conceptual underpinnings of INVs, IB scholars have adopted various theories and concepts to investigate the phenomenon of INVs, including the resourcebased (e.g., Knight and Cavusgil, 2004; Young, Dimitratos, \& Dana, 2003) and knowledge-based (e.g., Gassmann and Keupp, 2007) views of the firm, network perspective on internationalisation (e.g., Chetty and Campbell-Hunt, 2004), and transaction-cost perspective (e.g., Hennart, 2014).

In this paper, we mainly adopt an organisational learning theory perspective (e.g., Senge, 1990; Fiol and Lyles, 1985), as the role of learning has been widely acknowledged 
in the internationalisation process of firms (e.g., Johanson and Vahlne, 1990; 2009; Oviatt and McDougall, 1994). According to the behavioural theory of the firm (e.g., Cyert and March, 1963), a firm's market-related knowledge increases gradually over time due to the high costs of knowledge acquisition and the bounded rationality of the firm. The internationalisation process theory primarily bases its assumptions on the behavioural theory of the firm, and suggests that internationalisation is an incremental process of learning through which internationalising firms may accumulate knowledge over a period of time to avoid risks in international markets (Johanson and Vahlne, 1990; 2009). Such learning is important in determining not only the speed of internationalisation, but also the direction and the subsequent performance of the firm in overseas markets (Zahra, Ireland, \& Hitt, 2000; Mudambi and Zahra, 2007).

As defined by Levitt and March (1988: 320), organisational learning enables organisations to encode "inferences from history into routines that guide behaviour". As the internationalisation process generally poses challenges for the firm, due to its unfamiliarity with the institutional environment of host markets, experiential learning in the internationalisation process is often important to overcome the liabilities of foreignness (Eden and Miller, 2004; Zaheer, 1995; Zaheer and Mosakowski, 1997). Scholarship notes that learning may also provide important knowledge related to marketing, new product development and $R \& D$, thus facilitating internationalisation activities (Zahra et al., 2000; Yli-Renko, Autio, \& Tontti, 2002). Due to its key role, prior research suggests that learning facilitates the development and evolution of capabilities in INVs (Zahra, 2005).

The learning orientation of internationalising firms, including INVs, has been acknowledged to be critical for their internationalisation and subsequent capability development and evolution (Dimitratos and Plakoyiannaki, 2003; Baum et al., 2011; 
Zahra, 2005). As such, knowledge is considered as the key ingredient for the creation and development of INVs (Schwens and Kabst, 2011). Those INVs which take a continuous learning and knowledge development approach may well be in a superior position to exploit the opportunities available in international markets and, thus, be better able to deal with uncertainty and overcome the liabilities of newness and foreignness (Sapienza, Autio, George, \& Zahra, 2006). Thus, we can infer that it may be easier for INVs with a learning orientation to survive in the competitive international market compared with those lacking such a capability, as suggested by organisational learning theory. Such a learning orientation may positively influence the survival rates of firms in unchartered territories, which are prevalent in international markets, as INVs often continuously develop their knowledge bases by interacting with network partners (Weerawardena, Mort, Liesch, \& Knight, 2007; Bruneel, Yli-Renko, \& Clarysse, 2010; Zander et al., 2015). Our central argument is that those INVs with a strong learning orientation may be in a better position to take advantage of the additional opportunities available in international markets and may, thus, further enhance their firm performance.

Organisations often develop their strategies and capabilities on the basis of learning, and it is in this context that the role of organisational learning may be important in the development of new capabilities. Through the learning process, organisations encode experiential knowledge into their behavioural routines (Levitt and March, 1998). However, relatively few studies have examined how INVs' learning orientation may interact with a key set of resources and strategies, such as network resources and niche strategy, to further improve their firms' internationalisation process and performance (Clercq, Sapienza, \& Crijns, 2005; Coviello, 2015; Jones et al., 2011; Knight, 2015; Knight and Liesch, 2015; Zahra, 2005; Sapienza, De Clercq, \& Sandberg, 2005; Sui and Baum, 2014). 
The key aim of this paper is to investigate such relationships in the context of INVs' post-entry behaviour. This aim is in line with the suggestion by Coviello (2015), highlighting the need to disentangle the effects of learning, capabilities, strategy and performance of INVs.

\section{Niche orientation}

The literature offers some consensus on the viewpoint that INVs tend to undertake niche strategies based on specialised products/services that are provided to narrowly defined customer groups (Kuivalainen et al., 2007; Aspelund, Madsen, \& Moen, 2007; Knight and Cavusgil, 1996, 2004; Rennie, 1993). INVs tend to market specialised products/services to niche markets, while traditionally internationalising firms generally offer a diversified product/service range to broad market segments (Chetty and CampbellHunt, 2004). It has been suggested that INVs typically follow a differentiation and/or focus strategy, rather than a cost leadership approach (McDougall, Oviatt, \& Shrader, 2003; Knight and Cavusgil, 2005). This may be attributed to the difficulties of INVs, with respect to achieving economies of scale in production and/or marketing, which may result in their inability to compete on the basis of cost or volume against larger firms (Oviatt and McDougall, 1994; Knight and Cavusgil, 1996). It has been noted that the quality and value created through innovative technology and product design are the key competitive advantages for firms (Sisodia, 1992), including born globals (Rennie, 1993). However, some scholars argue that INVs may compete in both commodity and niche market segments (e.g., Fletcher, 2004; Bell, Crick, \& Young, 2004; Crick and Jones, 2000).

Recent research suggests that INVs, which have adopted a niche strategy, were more likely to survive in international markets compared to firms with a broad focus (e.g., Khan \& Lew, 2018). Autio (2017: 22) suggests that “... in the context of 
internationalization, a niche strategy should be more beneficial than a flexibility strategy [...] a niche strategy enables the new venture to focus its capability development efforts and achieve a good level of effectiveness more quickly than if the new venture attempted to develop a broad range of capabilities". However, the exact mechanisms through which a niche strategy may influence the post-entry performance of INVs is generally not well known (e.g., Knight and Cavusgil, 2004; Cavusgil and Knight, 2015; Knight and Liesch, 2015).

Knight and Cavusgil (2004) incorporated market orientation ${ }^{1}$ into their study of US-born global firms, and found that born globals' business strategies tend to be a function of their international marketing orientations. In turn, the firms' business strategies were generally drivers of the companies' international performance (Knight and Cavusgil, 2004). Blesa, Nauwelaerts, \& Ripollés (2008) found that niche orientation mediates the relationship between early international commitment and international positional advantages in terms of superior marketplace positions (e.g., Day, 1994). Positional advantages are based on deploying rare and hard to imitate resources and capabilities, which may help to improve company performance as per the resource-based view of the firm (Barney, 1991, 2001; Wernerfelt, 1984). In a similar vein, Matsuno, Mentzer, and Özsomer (2002) found a mediating effect of niche orientation on the relationship between entrepreneurial orientation and performance. However, Frishammar and Andersson (2009) found little support for a relationship between niche orientation and international performance, and suggested that niche orientation may assume a different meaning in small, international firms. Therefore, they called for the adaptation

\footnotetext{
${ }^{1}$ Knight and Cavusgil (2004) view market orientation primarily as a managerial mindset and the creation of value via key marketing elements for foreign customers. In this paper, we are more interested in the niche orientation of INVs, and how these firms compete in the global market.
} 
of the standard operationalisation of niche orientation to the specific context of international SMEs. We build on this call by Frishammar and Andersson (2009), and adapt Liesch, Steen, Middleton, and Weerawardena (2007) measures to operationalise niche orientation in the context of INVs.

In a qualitative study of Finnish software firms, Ruokonen and Saarenketo (2009) concluded that a high niche orientation combined with learning orientation may be a strong indicator of whether the companies are able to achieve a sustained competitive advantage and superior international performance. However, with regard to the association between niche orientation and firm performance in the literature, relatively little research has attempted to examine the mechanisms through which niche orientation may influence the post-entry performance of INVs (Fernhaber and Li, 2013; Coviello, 2015; Reuber, Dimitratos, \& Kuivalainen, 2017). Scholarship suggests that niche orientation in the INV context has not been fully explored (e.g., Hennart, 2014; Knight and Liesch, 2015). There seems to be limited understanding on how niche orientation interacts with other capabilities, such as learning orientation, in enhancing INVs' postentry performance (Jones et al., 2011; Cavusgil and Knight, 2015). Thus, a more subtle process may play a role in the potential impact of niche orientation on the post-entry performance of INVs, possibly through specific capabilities such as learning orientation, as INVs often experiment with new ways of operating in international markets (e.g., Autio, George, \& Alexy, 2011; Sapienza et al., 2005).

\section{Network resources}

The role of networks in the rapid rise of INVs is a recurring theme in the literature. Previous studies have emphasised the importance of networks for INVs (e.g., Chetty and Campbell-Hunt, 2004; Gerschewski, Lindsay, \& Rose, 2016). A salient feature of INVs 
pertains to their use of networks, which may result in hybrid governance structures, such as strategic alliances; this is presumed to be related to the firms' insufficient resources to support more standard internationalisation approaches (Oviatt and McDougall, 1994; McDougall, Shane, \& Oviatt, 1994; Hennart, 2014). Rialp, Rialp, and Knight (2005) concluded that born globals generally make strong use of personal and business networks, in order to compete internationally. Networks may provide valuable resources in the form of key knowledge and other resources that INVs can tap into in order to compete in international markets (Gulati, 1999; Fernhaber and Li, 2013).

In comparison, 'traditional' internationalising SMEs tend to rely more on conventional distribution channels, such as agents and distributors (Bell, McNaughton, Young, \& Crick, 2003). Similarly, Chetty and Campbell-Hunt (2004) found that born globals differ from 'traditional' internationalising firms in terms of the extent and pace of their network development with their business partners; i.e., INVs often use and develop a more extensive network to facilitate their rapid expansion in international markets, compared to 'traditional' firms.

When expanding abroad, firms may have to unlearn their established domestic routines and learn new routines and knowledge about international markets, which may conflict with their existing operations and the managements' mind-sets. As such, these young INVs may need to quickly learn about international market knowledge from their managers' extensive personal network contacts. For example, Andersson and Wictor (2003) noted that personal networks represent a key factor in the implementation of their internationalisation strategy and provide the main network for born globals, due to their young age and lack of stability in routines, systems and processes. Rialp et al. (2005) found that born globals tend to make more use of personal networks than traditional exporters do. Crick and Spence (2005) also emphasised the importance of existing 
networks, often resulting from the management's previous international experience, as resources that enabled firms to enter overseas markets successfully. Similarly, Zou and Ghauri (2010) found in a case study of three Chinese high-tech new ventures that the personal contacts of the senior management were the main source of network knowledge for the firms. These studies show that the personal contacts of INV managers helped them to expand in international markets.

The INV literature has attempted to differentiate between different types of network. Mort and Weerawardena (2006) identified fundamental networks, which allowed the exploitation of initial opportunities in international markets, while secondary networks were important in the firm's growth process. The authors noted that the strategic role of the founder/manager was critical in identifying and establishing both fundamental and secondary networks. This lends support to the importance of the management's personal networks, and can be linked to the entrepreneurial perspective on internationalisation, which highlights the role of the individual in the firm's internationalisation process (e.g., Andersson, 2000). Sharma and Blomstermo (2003) examined the strength of network ties (i.e., a combination of amount of time, emotional intensity, intimacy, reciprocity of services) and differentiated between weak and strong ties. The authors argued that weak ties are advantageous for born globals as they often provide more heterogeneous knowledge and are less costly to maintain than strong ties are. Using the case study of the born global company, Helax, Sharma and Blomstermo (2003) also highlighted the importance of the extensive personal ties of the chair of the company for the success of the firm's internationalisation endeavours. Freeman, Edwards, and Schroder (2006) argued that strong relationships with large foreign partners helped to overcome the constraints to rapid internationalisation, such as lack of economies of scale, and insufficient financial and knowledge resources. 
In sum, networks of INVs can serve as important 'resources' in the form of capital and knowledge for the firms' development of their capabilities for internationalisation. Thus, with these network resources, INVs may be able to overcome the liabilities of outsidership (Johanson and Vahlne, 2009), thereby gaining access to valuable international market knowledge embedded in their international networks. The impact of network resources on performance can be direct or indirect through other capabilities, such as learning orientation (Levitt and March, 1988). Yet to date, many studies have generally focused on network resources as an independent variable and detached it from learning orientation. As the impact of network resources on performance may differ across firms and industrial settings, the learning orientation of INVs can be one of the key capabilities through which we can better understand the impact of network resources on performance. This argument is consistent with the suggestions by Knight (2015), indicating the need to pay greater attention to the impact of learning orientation on the international performance of INVs.

\section{Mediating role of learning orientation and INV post-entry performance}

As noted earlier, learning orientation has its foundation in organisational learning theory, which views the firm as a learning organisation (e.g., Argote and Miron-Spektor, 2011; Senge, 1990; Fiol and Lyles, 1985). Organisational learning has been defined as the 'process of improving actions through better knowledge and understanding' (Fiol and Lyles, 1985: 803), and tends to be related to better business performance (Senge, 1990). Khan and Lew's (2018) recent case study shows that INVs' niche orientation and learning capability may provide a foundation for gaining a sustainable competitive advantage of the firm. More specifically, learning orientation refers to a mechanism that facilitates adaptive learning in the firm (Baker and Sinkula, 1999). Sinkula, Baker, and Noordewier (1997: 309) noted that learning orientation "influences the degree to which an 
organization is satisfied with its theory in use and, hence, the degree to which proactive learning occurs". 'Theory in use' primarily refers to the corporate culture of the firm, and this may be an important contextual variable for a better understanding of learning orientation. Firms with higher levels of learning orientation tend to encourage their employees to 'think outside the box' (Baker and Sinkula, 1999). Three organisational values have been conceptualised pertaining to the learning orientation of a firm (Sinkula et al., 1997; Senge, 1990): (1) commitment to learning, (2) open-mindedness, and (3) shared vision. Commitment to learning reflects the degree to which firms value learning and promote a learning culture. Open-mindedness is linked to the concept of 'unlearning', which includes the challenging of old routines, assumptions and beliefs. Baker and Sinkula (1999) noted that unlearning is at the heart of organisational change, and openmindedness is a prerequisite for the success of unlearning. Shared vision relates to the managerial direction of the learning process, in terms of helping employees to work towards a common goal (Sinkula et al., 1997). Learning orientation has been conceptualised as an organisational capability in several studies (e.g., Hult, Ketchen, \& Nichols, 2003; Collis, 1991; Uhlenbruck, Meyer, \& Hitt, 2003).

Firms with a high learning orientation are often in a better position to exploit the knowledge coming from their network, and they may use this knowledge to develop capabilities for specialised products for customers, develop a competitive advantage and outperform their rivals (e.g., Calantone, Cavusgil, \& Zhao, 2002; Wang, 2008). Learning orientation is associated with higher-order learning (e.g., Baker and Sinkula, 1999). As a result, INVs' learning orientation may facilitate niche strategies of products and service development and downstream market segments. Extant research has highlighted the key role of learning in the development of capabilities which, in turn, may explain the international growth of the firm (e.g., Kogut and Zander, 1992; Zahra et al., 2000). 
Despite the key role of learning orientation, with some exceptions (see e.g., Jantunen, Puumalainen, \& Saarenketo, 2008), relatively few studies have examined the role of learning orientation and performance implications in the INV context (Knight and Cavusgil, 2004; Coviello, 2015; Knight, 2015). The notion of 'learning advantages of newness' (Autio, Sapienza, \& Almeida, 2000) also indicates that successful INVs are often more flexible and quickly learn competencies required for growth in international markets (Sapienza et al., 2006). INVs with a high level of learning orientation may be better placed compared to their competitors to utilise the knowledge from different network resources and execute a niche strategy, thereby achieving superior performance. Thus, we posit that INVs' post-entry performance may depend on their developing a high level of learning orientation, in order to continuously upgrade their capabilities and take advantage of other resources, such as network attachment and niche orientation (Sapienza et al., 2006; Coviello, 2015; Knight and Liesch, 2015). Those INVs that adopt an active learning orientation and niche orientation in their cross-border operations may be in a better position to develop their competitive advantage (e.g., Autio, 2017). Based on the above discussion, we advance the following two hypotheses.

H1: An INV's learning orientation positively mediates the relationship between its niche orientation and post-entry performance.

H2: An INV's learning orientation positively mediates the relationship between its network resources and post-entry performance.

\section{METHODS}

\section{Sampling frame and data collection}

The study focus is to investigate the characteristics and mechanisms of INVs, which shape their post-entry firm performance. The sampling frame is based on 1,000 New Zealand and 1,000 Australian firms, which were established between 1999 and 2009. We gathered 
the company details primarily from the Dun \& Bradstreet database and supplementary internet-based desk research. The data collection was conducted through a web-based survey from April to July 2010. Using the above sampling frame, we developed a list of email addresses of 2,000 representative companies and sent each sample company an email invitation, which contained a link to the web-based survey. After the first round of the email survey, we conducted two additional rounds by sending follow-up reminder emails to non-responding companies. In sum, we collected 310 usable responses, accounting for a $15.5 \%$ response rate. We identified 147 INVs from the sample based on our definitions of INVs in terms of the time to internationalisation (i.e., start to internationalise within the first three years after establishment) and extent of internationalisation (i.e., at least $25 \%$ of international sales three years after the firm's establishment) (e.g., Knight and Cavusgil, 2004; Gerschewski et al., 2015). ${ }^{2}$

The survey respondents were primarily the companies' owners and/or CEOs (79\%), followed by company sales managers, such as export managers, and other senior management positions (21\%). Our sample of 147 INVs consists of 102 New Zealand and 45 Australian INVs, as shown in Table 1. The proportion of the sample size may be attributed to the fact that the surveys were administered and sent from New Zealand, and not from Australia. Therefore, a potential survey "country of origin" effect may explain the distribution of the sample firms.

After the data collection, we examined the non-response bias of the sample data. We categorised the data into early and late response groups, followed by conducting nonparametric Mann-Whitney U test to compare medians of dependent variables between

\footnotetext{
2 The original born global conceptualisation by Knight (1997) did not include the commonly used FSTS (Foreign Sales/Total Sales) ratio of 25\%. However, many subsequent studies (e.g., Andersson and Wictor, 2003; Gerschewski et al., 2015) have adopted the cut-off ratio of $25 \%$ FSTS.
} 
these two groups. We did not find any significant differences between the two groups ( $p>0.05$ ), suggesting that non-response bias is not a serious concern.

\section{$<$ Insert Table 1 about here $>>$}

\section{Common method bias}

As we collected data from single respondents, common method bias may potentially reside in the model (Podsakoff and Organ, 1986). We employed ex-ante and ex-post approaches to resolve the problem of common method bias. First, we emphasised the confidentiality and anonymity of the questionnaire response when we collected the data by clearly stating this on the first page of the survey. In addition, we randomised questions throughout our questionnaire, thus making it difficult for the respondents to make any assumptions regarding the conceptual model employed. These approaches also help to reduce social desirability bias (Schmitt, 1994). For ex-post solutions, we conducted Harman's one-factor analysis by using exploratory factor analysis. The results show that the largest single factor that was extracted explained only $21.4 \%$ of the total variance. In terms of the inter-construct correlation, the highest correlation between niche orientation and network resource was 0.364 (Bagozzi, Yi, \& Phillips, 1991). In addition, the high levels of internal consistency of our study constructs in the model support the assumption that the constructs are reliable in terms of their composite reliability (CR) and Cronbach's alpha scores. Therefore, we can conclude that common method bias probably does not impact our research findings.

\section{Measurement model}

We adapted the existing literature measures to operationalise the study constructs. We mainly used multi-item scales based on 7-point Likert scales from 1 (strongly disagree/not important at all) to 7 (strongly agree/extremely important). We operationalised niche 
orientation as the degree of an INV's product/service specialisation for overseas markets, the targeting of unexplored international market segments, the level of uniqueness of the INV's product/service in the firm's international marketing endeavours, the extent of how much the INV's product/service represents a new and innovative way of meeting a demand, and the level of the INV's product/service to serve an unmet market need (Khan and Lew, 2018). The items for niche orientation were mainly adapted from Liesch et al. (2007) and Moen (2002).

Network resource was operationalised as to what extent the business networks of management contribute to INVs' internationalisation. We operationalised network resource by adapting Andersson and Wictor's (2003) two items regarding the depth and breadth of previous personal networks.

In the conceptual model, learning orientation as a capability is hypothesised to facilitate the post-entry performance in the INVs' internationalisation process. Thus, we operationalise the learning orientation construct as the extent of an INV's continuous learning and knowledge development efforts in the internationalisation process. We adapted a four-item scale from Sinkula et al. (1997) to measure learning orientation.

We measured INVs' post-entry performance with three first-ordered constructs, i.e., operational, financial and overall effectiveness performance (Venkatraman and Ramanujam, 1986; Hult, Ketchen, Griffith, Chabowski, Hamman, Dykes, Pollitte, \& Cavusgil, 2008). With regard to the INVs' post-entry performance, we adopted a formative-reflective second-order hierarchical component model (HCM) (Becker, Klein, \& Wetzels, 2012; Chin 2010) in that the performance construct is a blend of the above 
three first-order performance constructs ${ }^{3} \quad$ (see e.g., Jarvis, MacKenzie, \& Podsakoff, 2003; Diamantopoulos and Siguaw, 2006; Petter, Straub, \& Rai, 2007). The high-order construct of INVs' post entry performance is a common concept of three formative loworder constructs (LOCs) (Venkatraman and Ramanujam, 1986; Hult et al. 2008), thus complementing the shortcomings of each single LOC (Becker et al., 2012).

Operational performance was measured using seven formative indicators: international market share, reputation, new product/service, presence of strategic locations, time to market for new product/service, gaining a foothold at an international level, and number of successful new products/services. Financial performance was measured with four formative indicators: international sales, sales growth, profitability, and return on investment from IB. Overall effectiveness was measured using two formative indicators: perceived IB success and overall IB performance (see Table 3). To capture the post-entry performance of INVs, we asked the respondents how satisfied they were with their 'company's main IB activities for the first five years after their company's initial internationalisation relative to their prior expectations'. ${ }^{4}$ When we tested the structural model, we included two control variables to control for firm size, measured as a number of employees, and firm age, as larger and older firms may have more international experiences and resources to achieve better international performance (see Figure 1).

\footnotetext{
${ }^{3}$ Regarding the advanced issue in formative-reflective HCM, Hair et al. (2018, p. 46) state, 'the objective of this HCM type is extracting the common part of several formatively measured low-order constructs (LOCs) that have been established to represent the same theoretical content ... the high-order construct represents the common part of the LOCs (i.e., overall firm performance)'.

${ }^{4} \mathrm{We}$ asked in the survey that respondents should evaluate their firms' international performance up to the time of the study (i.e., 2010), in case their firms had been doing international business for less than five years.
} 
Prior to testing the hypotheses, we checked measurement invariance as unforeseen latent heterogeneity may reside in the measurement model (Meyer, van Witteloostuijn, \& Beugelsdijk, 2017; Hair, Sarstedt, Ringle, \& Gudergan, 2018). Following Hair et al.'s (2018) non-parametric partial least squares (PLS) multi-group analysis approach, we made two sub-samples in terms of nationality (i.e., New Zealand and Australia). The result revealed no significant differences between the two nation samples, indicating that the respondents from New Zealand and Australia are unlikely to be heterogeneous in their assessments of latent constructs (Hair et al., 2018).

\section{$<<$ Insert Figure 1 about here $>>$}

\section{RESULTS}

\section{Reliability and validity}

We assessed reliability using Cronbach's alpha and CR. As shown in Table 3, the values of Cronbach's alpha of most of the constructs were above 0.8 , except for network resource $($ alpha $=0.662)$. For an exploratory study, Nunnally (1978) suggests a threshold of 0.6, and the CR values of all constructs were higher than 0.8 . Therefore, we can conclude that internal consistency reliability exists in the measurement model. We checked indicator reliability using the absolute standardised outer loadings on all items in the model, and they indicate a high level of indicator reliability in the measurement model (see Table 2).

We examined convergent validity using average variance extracted (AVE) (Fornell and Larker, 1981). The values of all constructs were over 0.5 (see Table 2). Discriminant validity was assessed by comparing the AVE of each construct with the highest value of the squared correlation among the study constructs (Hair et al., 2018). The diagonal values in Table 2 are the scores of the square root of the AVE, which are 
not lower than the highest correlation among the study constructs, suggesting that discriminant validity is evident for the model.

$<$ Insert Table 2 and Table 3 about here $>>$

\section{PLS structural equation modelling}

We assessed the structural model using PLS structural equation modelling (PLS-SEM) for the following reasons. As discussed in the theory section, limited research has examined the association between the internationalisation and post-entry performance of INVs (e.g., Trudgen and Freeman, 2014). Therefore, a variance-based PLS-SEM method is suitable for testing an exploratory theory (Henseler, Ringle, \& Sarstedt, 2016). This research investigates the relatively underexplored INVs' post-entry performance by using PLS-SEM. In addition, it is appropriate for testing our relatively small sample $(n=147)$, as PLS analytics do not strictly assume a normal sample distribution (Lew and Sinkovics, 2013), and the bootstrap method in PLS allows the small sample to test the confidence intervals for each path coefficient of the model (Carrión, Henseler, Ringle, \& Roldán, 2016). Next, our study constructs contain many indicators and the model consists of complex relationships, including a latent construct and a formative-reflective secondorder performance construct (Becker et al. 2012); thus, PLS-SEM is a suitable analytical solution for this study.

\section{Hypothesis testing}

The PLS-SEM analysis results revealed a mediating effect of learning orientation on the relationship between niche orientation and post-entry performance. When we removed learning orientation from the model, the relationship between niche orientation and postentry performance was positively significant $(b=0.224, p<0.01)$. However, when learning orientation was included in the model, the path from niche orientation and post-entry 
performance became insignificant $(b=-0.035)$, as shown in Figure 1. At the same time, the path from niche orientation to learning orientation $(b=0.336, p<0.01)$ and that from learning orientation to post-entry performance $(b=0.212, p<0.1)$ were positively significant. $\mathrm{Hl}$ is strongly supported based on evidence for full mediation (Baron and Kenny, 1986).

Following the above approach, we assessed the mediating effect of learning orientation on the relationship between network resource and post-entry performance. There was an insignificant direct relationship between network resource and post-entry performance at the 0.05 level $(b=0.045)$. When we put learning orientation as a mediator, the association between network resource became insignificant $(b=0.054)$, while the path from network resource to learning orientation $(b=0.192, p<0.01)$ and the relationship between learning orientation and post-entry performance $(b=0.212, p<0.05)$ were significant. Based on this, $\mathrm{H} 2$ is supported, as the mediated effect ((a) the path from network resource to learning orientation and (b) the path from learning orientation to postentry performance) exists, but there is (c) no direct effect, i.e., indirect-only meditation (Zhao, Lynch, \& Chen, 2010). In other words, network resource tends to strongly facilitate the INVs' learning orientation which, in turn, strongly affects their post-entry performance, while no direct significant association between network resource and postentry performance was found in our model.

We assess the predictive power of the model with the $\mathrm{R}^{2}$ value of two endogenous constructs (i.e., learning orientation and post-entry performance). Their $\mathrm{R}^{2}$ values were 0.17 and 0.08 respectively (Falk and Miller, 1981), suggesting the predictive power of the model. As shown in Figure 1, the $\mathrm{R}^{2}$ value of multi-dimensional post-entry performance is 0.08 in the full model. We compared the $\mathrm{R}^{2}$ value of the model, including all of the constructs with that of the learning orientation excluded model. When it was 
excluded from the model, the $\mathrm{R}^{2}$ value of the post-entry performance was 0.054 . In addition, we examined the predictive relevance of the endogenous constructs in terms of the $Q^{2}$ values of the cross-validated redundancy and cross-validated communality (Fornell and Cha, 1994). The results showed that the $Q^{2}$ values of the two endogenous latent constructs (i.e., learning orientation and post-entry performance) were over 0 , suggesting the existence of predictive relevance.

\section{DisCuSSION AND CONCLUSION}

The main purpose of this article was to examine the post-entry performance of INVs in line with the notion that empirical studies are still in their relative infancy (e.g., Coviello, 2015; Gerschewski et al., 2015; Knight and Cavusgil, 2015; Mudambi and Zahra, 2007). Scholars have noted that network, innovation and capabilities may be the key underlying factors explaining the post-entry performance of INVs (e.g., Knight and Cavusgil, 2004, 2015; Mudambi and Zahra, 2007). In addition to these research contributions, scholars have called for further research to better understand the resources, strategies, and capabilities that may enhance the post-entry performance of INVs (e.g., Autio, 2017; Jones et al., 2011; Cavusgil and Knight, 2015; Coviello, 2015; Knight, 2015; Gerschewski et al., 2015).

In this paper, we narrow our focus onto examining the influence of network as a resource, niche orientation as a focused strategy, and learning orientation as a key capability, as these are often considered central to understanding the post-entry performance of INVs (e.g., Cavusgil and Knight, 2015; Coviello, 2015; Knight, 2015). Based on the extant literature, we develop a conceptual model and put forward two hypotheses, which may shed important light on the antecedents of INVs' post-entry performance. 
In $\mathrm{H} 1$, we estimated the mediating effect of learning orientation on the relationship between the niche orientation and post-entry performance of INVs. We find support for the hypothesis that a niche strategy is important in explaining the post-entry performance of INVs, and that this impact may be explained by their learning orientation. In $\mathrm{H} 2$, we proposed that network resource is one of the important resources in enhancing the post-entry performance of INVs; however, the mechanisms and underlying capabilities through which network resource can influence the post-entry performance of INVs are generally not well developed. In this context, we theorise that the mediating effect of learning orientation is one of the capabilities through which network resources may influence the post-entry performance of INVs, and find an indirect-only mediating effect (Zhao et al., 2010), indicating the importance of learning orientation in the postinternationalisation process of INVs. This finding is important as it provides key insights about the subtle underlying process (e.g., learning orientation) through which resources and business strategies may impact the post-entry performance of INVs. Some empirical studies have addressed the concept of learning orientation and generally found it to be positively related to organisational performance, in terms of new product success, change in relative market share, and overall performance (Baker and Sinkula, 1999), and innovativeness (Hult, Hurley, \& Knight, 2004). In addition, some authors found a mediating effect of learning orientation on the relationship between entrepreneurial orientation and firm performance (e.g., sales growth, earnings per share) (Wang, 2008), while others suggested a positive relationship between learning and market orientation (Mavondo, Chimhanzi, \& Stewart, 2005). Zahra et al. (2000) found support for a positive relationship between international expansion and the breadth, depth and speed of technological learning. Baker and Sinkula (1999) concluded that the combination of a strong market and learning orientation is associated with a long-term competitive 
advantage. However, these studies have generally not examined such relationships in the context of the post-entry performance of INVs.

The mediating role of learning orientation between niche orientation and network resource in explicating the post-entry performance of INVs is a core finding of the present study. Those INVs with a higher learning orientation will likely be in a better position to enhance their post-entry performance, compared to those with a low learning orientation. In doing so, we shed light on the subtle relationship through which INVs' resources, strategies and capabilities may explain their differential post-entry performance. In addition, our post-hoc analyses further demonstrate that learning orientation may matter in both the manufacturing and services sector contexts. These insights thus provide a more granular view of the post-entry performance of INVs by establishing a mediating link between the learning orientation as a key capability, network resources, and business strategies of INVs.

\section{Theoretical implications}

In this study, we contribute to the emerging literature on explaining the post-entry behaviour of INVs by suggesting that learning orientation is one of the key capabilities through which their network resources and strategies may interact with each other and influence the post-entry performance of these firms. In doing so, the paper offers several implications for research on INVs, as well as for the network, organisational learning, and strategy streams of the literature.

First, we refine the existing literature, which has generally focused on capabilities, innovation, and network relationships (e.g., Knight and Cavusgil, 2004; Weerawardena et al., 2007; Mudambi and Zahra, 2007), by integrating the INVs' learning 
orientation as a key 'capability' through which their niche orientation and network resource may impact on their firms' post-entry performance. Thus, we enhance our understanding of the underlying mechanisms through which the INVs' focused strategy (e.g., targeting niche customers in international markets) and networks as a key resource may enhance their post-entry performance through the mediating effect of the firms' learning orientations (e.g., Coviello, 2015; Knight, 2015).

Second, we build on the relatively scarce literature on the post-entry performance of INVs by attempting to understand the capabilities and underlying resources and strategies, which may explain the post-entry performance of these rapidly internationalising firms (e.g., Cavusgil and Knight, 2015; Mudambi and Zahra, 2007; Sui and Baum, 2014). Our study contributes to the literature on the determinants of the postentry performance of INVs by simultaneously considering the roles of the firms' resources, business strategies and capabilities on their company performance, which has received less attention in the literature (e.g., Autio, 2017; Coviello, 2015; Knight, 2015; Knight and Liesch, 2015; Gerschewski et al., 2015).

Third, the study findings have implications for organisational learning theory by unravelling the role of the learning orientation of firms in their internationalisation strategies and post-entry performance. Learning orientation is often considered a key capability, via which INVs can use the learning and apply valuable knowledge across international markets, thus enhancing the firms' post-entry performance (Argote and Miron-Spektor, 2011; Fiol and Lyles, 1985). In this study, learning orientation serves as a mediator in the relationships between the niche orientation (full mediation) and network resources (indirectly-only mediation) of INVs, and has a positive impact on post-entry performance. As such, our findings provide deeper insights into the existing literature on 
organisational learning and internationalisation (e.g., Sapienza et al., 2006, Weerawardena et al., 2007; Bruneel et al., 2010; Zander et al., 2015), in terms of why and how these mediating relationships exist. Our findings provide key insights into the strategy and network literature by demonstrating the manner in which network resources and a niche strategy may be crucial for the internationalisation and expansion of INVs these factors may need to be integrated with the learning orientation of the INVs, in order to improve the firms' respective post-entry performance.

\section{Managerial implications}

First, the study findings suggest that organisational level capabilities, network resources, and strategies are key drivers in enhancing the international performance of INVs. Thus, INV managers are well advised to carefully evaluate the underlying learning capabilities, network resources, and business strategies for how their firms are competing, in order to improve their firm performance in international markets, while simultaneously increasing the firms' survivability.

Second, it is generally very important for managers to be aware that INVs may be able to learn specific international market information by targeting niche markets and enlarging the firms' internal knowledge reservoir through network resources. This indicates that network resources may lead to the expansion of net-widening effects in personal connections, and, subsequently, may function as a vehicle to learn external information from active contacts and communications within the firms' network. Knowledge acquisition through the use of both focused niche strategy and network resources may logically enhance firm performance. In this vein, managers need to understand that niche strategy and network resources per se may not enable their firms to improve their post-entry performance, if they fail to develop appropriate learning 
capabilities. The implications are that managers should be mindful of the learning process, routines, and mechanisms adopted for improving firm performance. As a result, managers may apply diverse knowledge across multiple international markets, thus improving their company performance.

\section{Limitations and future research}

First, we focus on some of the key organisational level orientations and capabilities in attempting to better understand the post-entry performance of INVs. Future studies could build on these findings and identify additional orientations and capabilities, such as the effects of the exploratory and exploitative innovation capabilities and speed of learning of INVs on the firms' post-entry performance, by taking a sample of INVs from both developed and emerging markets. Second, we focus on the mediating role of learning orientation as a key part of organisational capability of INVs. However, other potential capability-related mediators (e.g., organisational structure and leadership) may be associated with the INVs' post-entry performance (e.g., Zhao et al., 2010). Future studies may integrate such variables into the model to examine how they may interact with capabilities to explain the post-entry performance of INVs in a comparative context (e.g., INVs vs. non-INVs). In addition, as the data are cross-sectional in nature, there is the possibility of reverse causality between some of the key variables. We acknowledge this issue as one of the research limitations.

Third, in terms of the survey measures, we operationalised 'network resources' by drawing primarily on Andersson and Wictor (2003). Future studies may adopt alternative, more fine-grained, measures of network resources to further capture the postentry performance of INVs. In addition, our survey respondents were asked to comment on what is occurring in the minds of managers (e.g., learning orientation). Although it is 
difficult to measure an organisational-level construct, our psychometric approach can be complemented with multi-level and paced surveys (Bliese, Chan, \& Ployhart, 2007). In terms of firm performance, the industry context and lifecycle of the firm may provide additional insights into the post-entry performance of INVs. As a result, future studies could pay greater attention to the industry lifecycle, and how this may influence the postentry performance of INVs, using both primary and secondary sources for performance data. Fourth, we collected data from single key knowledgeable informants, which offers both advantages and disadvantages (e.g., Kumar, Stern, \& Anderson, 1993). Key informants (e.g., key decision makers in firms) can provide valuable information about the events and strategies adopted by the INVs, but the key informants may also provide biased and/or unreliable information. Thus, we recommend future studies collect data from multiple respondents on the independent and dependent variables, and adopt mixed methods, in order to mitigate such potential disadvantages.

In addition, this study is mainly exploratory and uses PLS research methods, which do not assume a strictly normal distribution on the sample, although we have used a bootstrapping technique for testing the model. There could be additional mediating variables, which may explain the post-entry performance of INVs (e.g., Zhao et al., 2010). It seems to be a promising research avenue to further explore complementary constructs, such as opportunity development, technological capabilities, and the breadth and depth of learning, to enhance our understanding of the post-entry performance of INVs (e.g., Romanello, Masoud, Gerschewski, \& He, 2018). Finally, we acknowledge that each performance measure (i.e., objective vs. subjective assessment) has its own advantages and disadvantages. We suggest future studies capture both objective and subjective performance measures at different timeframes, in order to develop a holistic view of the post-entry performance of INVs. 


\section{REFERENCES}

Andersson S (2000). The internationalization of the firm from an entrepreneurial perspective. International Studies of Management \& Organization, 30(1), 63-92.

Andersson S and Wictor I (2003). Innovative internationalisation in new firms: born globals - the Swedish case. Journal of International Entrepreneurship 1(3): 249-275.

Argote L and Miron-Spektor E (2011). Organizational learning: From experience to knowledge. Organization Science 22(5): 1123-1137.

Aspelund A, Madsen TK and Moen $\varnothing$ (2007). A review of the foundation, international marketing strategies, and performance of international new ventures. European Journal of Marketing 41(11/12): 1423-1448.

Autio E, Sapienza HJ and Almeida JG (2000). Effects of age at entry, knowledge intensity, and imitability on international growth. Academy of Management Journal 43(5): 909-924.

Autio E (2017). Strategic entrepreneurial internationalization: A normative framework. Strategic Entrepreneurship Journal 11(3): 211-227.

Autio E, George G and Alexy O (2011). International entrepreneurship and capability development: Qualitative evidence and future research directions. Entrepreneurship Theory and Practice 35(1): 11-37.

Bagozzi RP, Yi Y, and Phillips, LW (1991). Assessing construct validity in organizational research. Administrative Science Quarterly, 36(3): 421-458.

Baker WE and Sinkula JM (1999). The synergistic effect of market orientation and learning orientation on organizational performance. Journal of the Academy of Marketing Science 27(4): 411-427.

Barney JB (1991). Firm resources and sustained competitive advantage. Journal of Management 17: 99-120.

Barney JB (2001). Is the resource-based 'view' a useful perspective for strategic management research? Yes. Academy of Management Review 26(1): 41-56.

Baron RM and Kenny DA (1986). The Moderator-Mediator Variable Distinction in Social Psychological Research - Conceptual, Strategic, and Statistical Considerations. Journal of Personality and Social Psychology 51(6): 11731182.

Baum M, Schwens C and Kabst R (2011). A typology of international new ventures: empirical evidence from high-technology industries. Journal of Small Business Management 49(3): 305-330.

Becker J-M, Klein K and Wetzels M (2012). Hierarchical Latent Variable Models in PLSSEM: Guidelines for Using Reflective-Formative Type Models. Long Range Planning 42(5-6): 359-394. 
Bell J, McNaughton R, Young S and Crick D (2003). Towards an integrative model of small firm internationalisation. Journal of International Entrepreneurship 1(4): 339-362.

Bell J, Crick D and Young S (2004). Small firm internationalization and business strategy: an exploratory study of 'knowledge-intensive' and 'traditional' manufacturing firms in the UK. International Small Business Journal 22(1): 23-56.

Blesa A, Monferrer D, Nauwelaerts Y and Ripollés M (2008). The effect of early international commitment on international positional advantages in Spanish and Belgian international new ventures. Journal of International Entrepreneurship 6(4): 168-187.

Bliese PD, Chan D and Ployhart RE (2007). Multilevel methods: Future directions in measurement, longitudinal analyses, and nonnormal outcomes. Organizational Research Methods 10(4): 551-563.

Bruneel J, Yli-Renko H and Clarysse B (2010). Learning from experience and learning from others: how congenital and interorganizational learning substitute for experiential learning in young firm internationalization. Strategic Entrepreneurship Journal 4(2): 164-182.

Calantone RJ, Cavusgil ST and Zhao Y (2002). Learning orientation, firm innovation capability, and firm performance. Industrial Marketing Management 31(6): 515-524.

Carrión GC, Henseler J, Ringle CM and Roldán JL (2016). Prediction-oriented modeling in business research by means of PLS path modeling: introduction to a JBR special section. Journal of Business Research 69(10): 4545-4551.

Cavusgil ST and Knight G (2015). The born global firm: An entrepreneurial and capabilities perspective on early and rapid internationalization. Journal of International Business Studies 46(1): 3-16.

Chetty S and Campbell-Hunt C (2004). Internationalisation strategy and its impact on learning during the process. Journal of Asia Pacific Marketing 3(2): 38-52.

Chin WW (2010). How to Write Up and Report PLS Analyses, in Handbook of Partial Least Squares, Vinzi VE, Chin WW, Henseler J and Wang H. eds. $1^{\text {st }}$ ed. Berlin: Springer, 655-690.

Clercq DD, Sapienza HJ and Crijns H (2005). The internationalization of small and medium-sized firms. Small Business Economics 24(4): 409-419.

Collis DJ (1991). A resource-based analysis of global competition: the case of the bearings industry. Strategic Management Journal 12(1): 49-68.

Coviello N (2006). The network dynamics of international new ventures. Journal of International Business Studies 37(5): 713-731.

Coviello N (2015). Re-thinking research on born globals. Journal of International Business Studies 46(1): 17-26. 
Crick D and Jones M (2000). Small high-technology firms and international hightechnology markets. Journal of International Marketing 8(2): 63-85.

Crick D and Spence M (2005). The internationalisation of 'high performing' UK hightech SMEs: a study of planned and unplanned strategies. International Business Review 14(2): 167-185.

Cyert RM., and March JG (1963). A behavioral theory of the firm. Englewood Cliffs: Prentice-Hall.

Day GS (1994). The capabilities of market-driven organizations. Journal of Marketing 58: $37-52$

Dimitratos P and Plakoyiannaki E (2003). Theoretical foundations of an international entrepreneurial culture. Journal of International Entrepreneurship 1(2): 187215.

Diamantopoulos A and Siguaw JA (2006). Formative versus reflective indicators in organizational measure development: A comparison and empirical illustration. British Journal of Management 17(4): 263-282.

Eden L and Miller SR (2004). Distance matters: Liability of foreignness, institutional distance and ownership strategy. Advances in International Management $16: 187-221$.

Falk RF and Miller NB (1981). A Primer for Soft Modeling. Akron: The University of Akron Press, Akron.

Fernhaber SA and Li D (2013). International exposure through network relationships: Implications for new venture internationalization. Journal of Business Venturing 28(2): 316-334.

Fiol CM and Lyles MA (1985). Organizational learning. Academy of Management Review 10(4): 803-813.

Fletcher D (2004). International entrepreneurship and the small business. Entrepreneurship \& Regional Development 16(4): 289-305.

Fornell C and Cha J (1994). Partial least squares. In: Bagozzi, R.P. (Ed.), Advanced Methods of Marketing. Cambridge: Blackwell, 55-78.

Fornell C and Larcker DF (1981). Evaluating structural equation models with unobservable variables and measurement error. Journal of Marketing Research 18(1): 39-50.

Freeman S, Edwards R and Schroder B (2006). How smaller born-global firms use networks and alliances to overcome constraints to rapid internationalization. Journal of International Marketing 14(3): 33-63.

Frishammar J and Andersson S. (2009). The overestimated role of strategic orientations for international performance in smaller firms. Journal of International Entrepreneurship 7(1): 57-77. 
Gassmann O and Keupp MM (2007). The competitive advantage of early and rapidly internationalising SMEs in the biotechnology industry: A knowledge-based view. Journal of World Business 42(3): 350-366.

Gerschewski S, Rose EL and Lindsay VJ (2015). Understanding the drivers of international performance for born global firms: An integrated perspective. Journal of World Business 50(3): 558-575.

Gerschewski S and Xiao SS (2015). Beyond financial indicators: An assessment of the measurement of performance for international new ventures. International Business Review 24(4): 615-629.

Gerschewski S, Lindsay VJ and Rose EL (2016). Advancing the entrepreneurial orientation construct: The role of passion and perseverance. Review of International Business and Strategy 26(4): 446-471.

Gulati, R (1999). Network location and learning: The influence of network resources and firm capabilities on alliance formation. Strategic Management Journal 20(5): 397-420.

Hair JJ, Sarstedt M, Ringle CM and Gudergan SP (2018). Advanced Issues in Partial Least Squares Structural Equation Modeling. Thousand Oak: Sage.

Hennart J-F (2014). The accidental internationalists: A theory of born globals. Entrepreneurship Theory and Practice 38(1): 117-135.

Henseler J, Ringle CM and Sarstedt M (2016). Testing measurement invariance of composites using partial least squares. International Marketing Review 33(3): 405-431.

Hult GTM, Ketchen DJ and Nichols EL. (2003). Organizational learning as a strategic resource in supply management. Journal of Operations Management 21(5): 541-556.

Hult GTM, Hurley RF and Knight GA (2004). Innovativeness: Its antecedents and impact on business performance. Industrial Marketing Management 33(5): 429-438.

Hult GTM, Ketchen DJ, Griffith DA, Chabowski BR, Hamman MK, Dykes BJ, Pollitte WA and Cavusgil ST (2008). An Assessment of the Measurement of Performance in International Business Research. Journal of International Business Studies 39(6): 1064-1080.

Inkpen, AC and Tsang EW (2005). Social capital, networks, and knowledge transfer. Academy of Management Review 30(1): 146-165.

Jantunen A, Nummela N, Puumalainen K and Saarenketo S (2008). Strategic orientations of born globals - Do they really matter? Journal of World Business 43(2): 158170 .

Jarvis D, MacKenzie S and Podsakoff P (2003). A critical review of construct indicators and measurement model misspecification in marketing and consumer research. Journal of Consumer Research 30(3): 199-218. 
Johanson J and Vahlne JE (1990). The mechanism of internationalisation. International Marketing Review 7(4): 11-24.

Johanson J and Vahlne JE (2009). The Uppsala internationalization process model revisited: From liability of foreignness to liability of outsidership. Journal of International Business Studies 40(9): 1411-1431.

Jones MV, Coviello N and Tang YK (2011). International entrepreneurship research (1989-2009): a domain ontology and thematic analysis. Journal of Business Venturing 26(6): 632-659.

Khan Z and Lew YK (2018). Post-entry survival of developing economy international new ventures: A dynamic capability perspective. International Business Review 27(1): 149-160.

Knight GA (2015). Born global firms: Evolution of a contemporary phenomenon. In Entrepreneurship in International Marketing Emerald Group Publishing Limited, 3-19.

Knight GA and Liesch PW (2015). Internationalization: from incremental to born global. Journal of World Business 51(1): 93-102.

Knight GA (1997). Emerging paradigm for international marketing: The born-global firm. Unpublished doctoral dissertation, Michigan State University, East Lansing, MI.

Knight GA and Cavusgil ST (1996). The born global firm: A challenge to traditional internationalization theory. In ST Cavusgil \& TMadsen (Eds.), Advances in International Marketing. Greenwich, CT: JAI Press.

Knight GA and Cavusgil ST (2004). Innovation, organizational capabilities, and the bornglobal firm. Journal of International Business Studies 35(2): 124-141.

Knight GA and Cavusgil ST (2005). A taxonomy of born global firms. Management International Review 45(3): 15-35.

Kogut B and Zander U. (1992). Knowledge of the firm, combinative capabilities, and the replication of technology. Organization Science 3(3): 383-397.

Kohli AK and Jaworski BJ (1990). Market orientation: the construct, research propositions, and managerial implications. Journal of Marketing 50(4): 1-18.

Kuivalainen O, Saarenketo S and Puumalainen, K (2012). Start-up patterns of internationalization: A framework and its application in the context of knowledge-intensive SMEs. European Management Journal 30(4): 372-385.

Kuivalainen O, Sundqvist S and Servais P (2007). Firms' degree of born-globalness, international entrepreneurial orientation and export performance. Journal of World Business 42(3): 253-267.

Kumar N, Stern LW and Anderson, JC (1993). Conducting interorganizational research using key informants. Academy of Management Journal 36(6):1633-1651. 
Larimo J (2003). Form of investment by Nordic firms in world markets. Journal of Business Research 56(10): 791-803.

Levitt, B and March JG (1988). Organizational learning. Annual Review of Sociology 14: 319-340.

Lew YK and Sinkovics RR (2013). Crossing borders and industry sectors: behavioral governance in strategic alliances and product innovation for competitive advantage. Long Range Planning 46(1): 13-38.

Lew YK, Sinkovics RR and Kuivalainen O (2013). Upstream internationalization process: Roles of social capital in creating exploratory capability and market performance. International Business Review 22(6): 1101-1120.

Liesch P, Steen M, Middleton, S and Weerawardena J (2007). Born to be global: A closer look at the international venturing of Australian born global firms. Australian Business Foundation.

Loane S and Bell J (2006). Rapid internationalisation among entrepreneurial firms in Australia, Canada, Ireland and New Zealand: An extension to the network approach. International Marketing Review 23(5): 467-485.

Matsuno K, Mentzer JT and Özsomer A (2002). The effects of entrepreneurial proclivity and market orientation on business performance. Journal of Marketing 66(3): 18-32.

Mavondo FT, Chimhanzi J and Stewart J (2005). Learning orientation and market orientation: Relationship with innovation, human resource practices and performance. European Journal of Marketing 39(11/12):1235-1263.

McDougall PP, Oviatt BM and Shrader RC (2003). A comparison of international and domestic new ventures. Journal of International Entrepreneurship, 1(1), 59-82.

McDougall PP, Shane S and Oviatt BM (1994). Explaining the formation of international new ventures: The limits of theories from international business research. Journal of Business Venturing, 9, 467-487.

Meyer, KE, van Witteloostuijn, A and Beugelsdijk S (2017). What's in a P? Reassessing best practices for conducting and reporting hypothesis-testing research. Journal of International Business Studies 48(5): 535-551.

Moen $\varnothing$ (2002). The born globals: a new generation of small European exporters. International Marketing Review 19(2): 156-175.

Morgan-Thomas A and Jones MV (2009). Post-entry internationalization dynamics: differences between SMEs in the development speed of their international sales. International Small Business Journal 27(1): 71-97.

Mort, GS and Weerawardena J (2006). Networking capability and international entrepreneurship - How networks function in Australian born global firms. International Marketing Review 23(5): 549-572.

Mudambi R and Zahra SA (2007). The survival of international new ventures. Journal of International Business Studies 38(2): 333-352. 
Nunnally J (1978). Psychometric Theory, New York: McGraw-Hill.

Oviatt BM and McDougall PP (1994). Toward a theory of international new ventures. Journal of International Business Studies 25(1): 45-64.

Petter S, Straub D and Rai A (2007). Specifying formative construct in information system research. MIS Quarterly, 31, 623-656.

Pinfold JF (2000). Examining new venture failure rates: A New Zealand study. Small Enterprise Research 8(1): 56-72.

Podsakoff PM and Organ DW (1986). Self-reports in organizational research: Problems and prospects. Journal of Management 12, 69-82.

Racela OC, Chaikittisilpa C and Thoumrungroje A (2007). Market orientation, international business relationships and perceived export performance. International Marketing Review 24(2): 144-163.

Rennie MW (1993). Born global. McKinsey Quarterly, 4, 45-52.

Reuber AR, Dimitratos P and Kuivalainen O (2017). Beyond categorization: New directions for theory development about entrepreneurial internationalization. Journal of International Business Studies 48(4): 411-422.

Rialp A, Rialp J and Knight GA (2005). The phenomenon of early internationalizing firms: what do we know after a decade (1993-2003) of scientific inquiry?. International Business Review 14(2): 147-166.

Romanello R, Masoud K, Gerschewski S and He, C. X. (2018). The exploration of international opportunities in born global firms: The role of institutions. Proceedings of McGill International Entrepreneurship Conference 2018, Halmstad University, Sweden.

Ruokonen M and Saarenketo S (2009). The strategic orientations of rapidly internationalizing software companies. European Business Review 21(1): 1741.

Sapienza, HJ, Autio E, George G and Zahra SA (2006). A capabilities perspective on the effects of early internationalization on firm survival and growth. Academy of Management Review 31(4): 914-933.

Sapienza, HJ, De Clercq D and Sandberg WR. (2005). Antecedents of international and domestic learning effort. Journal of Business Venturing 20(4): 437-457.

Schmitt N (1994). Method bias: The importance of theory and measurement. Journal of Organizational Behavior, 15: 393-398.

Schwens, C and Kabst, R (2008). How early internationalizers venture abroad: A review. In R. Moser (Ed.), Ausländische Direktinvestitionen: Neuere Entwicklungen, Entscheidungsinstrumente und führungsrelevante Folgen. Wiesbaden: Gabler.

Schwens C and Kabst R. (2011). Internationalization of young technology firms: A complementary perspective on antecedents of foreign market familiarity. International Business Review 20(1): 60-74. 
Senge P (1990). The fifth discipline: The art and science of the learning organization. New York: Currency Doubleday.

Sharma, DD and Blomstermo A (2003). The internationalization process of born globals: A network view. International Business Review 12(6): 739-753.

Sinkula JM, Baker WE and Noordewier T (1997). A framework for market-based organizational learning: Linking values, knowledge, and behavior. Journal of the Academy of Marketing Science, 25(4): 305-318.

Sisodia RS (1992). Competitive advantage through design. Journal of Business Strategy, 13(6): 33-40.

Sui S and Baum M (2014). Internationalization strategy, firm resources and the survival of SMEs in the export market. Journal of International Business Studies 45(7): 821-841.

Trudgen R and Freeman S (2014). Measuring the performance of born-global firms throughout their development process: The roles of initial market selection and internationalisation speed. Management International Review 54(4), 551-579.

Uhlenbruck K, Meyer KE and Hitt MA (2003). Organizational transformation in transition economies: resource-based and organizational learning perspectives. Journal of Management Studies 40(2): 257-282.

Venkatraman N and Ramanujam V (1986). Measurement of business performance in strategy research: A comparison of approaches. Academy of Management Review 11(4): 801-814.

Wang CL (2008). Entrepreneurial orientation, learning orientation, and firm performance. Entrepreneurship Theory and Practice 32(4): 635-657.

Weerawardena J, Mort, GS, Liesch PW and Knight G (2007). Conceptualizing accelerated internationalization in the born global firm: A dynamic capabilities perspective. Journal of World Business 42(3): 294-306.

Wernerfelt B (1984). A resource-based view of the firm. Strategic Management Journal 5(2): 171-180.

Yli-Renko H, Autio E and Tontti V (2002). Social capital, knowledge, and the international growth of technology-based new firms. International Business Review 11(3): 279-304.

Young S, Dimitratos P and Dana LP (2003). International entrepreneurship theories: What scope for international business theories? Journal of International Entrepreneurship 1(1): 31-42.

Zaheer S (1995). Overcoming the liability of foreignness. Academy of Management Journal 38(2): 341-363.

Zaheer S and Mosakowski E (1997). The dynamics of the liability of foreignness: A global study of survival in financial services. Strategic Management Journal 18(6): 439-463. 
Zahra SA (2005). A theory of international new ventures: a decade of research. Journal of International Business Studies 36(1): 20-28.

Zahra SA, Ireland RD and Hitt MA (2000). International expansion by new venture firms: International diversity, mode of market entry, technological learning, and performance. Academy of Management Journal 43(5): 925-950.

Zander I, McDougall-Covin P and Rose EL (2015). Born globals and international business: Evolution of a field of research. Journal of International Business Studies 46(1): 27-35.

Zhao X, Lynch JG and Chen Q (2010). Reconsidering Baron and Kenny: Myths and truths about mediation analysis. Journal of Consumer Research 37(2): 197-206.

Zou H and Ghauri PN (2010). Internationalizing by learning: the case of Chinese hightech new ventures. International Marketing Review 27(2): 223-244. 


\section{TABLES AND FigureS}

Table 1 Sample characteristics

\begin{tabular}{|c|c|}
\hline Number of Firms & 147 firms (102 New Zealand, 45 Australia) \\
\hline Annual Sales in 2009 (NZ/A\$) & Mean: 1-5 million \\
\hline Number of Employees & Mean: 23.4; SD ${ }^{1}: 43.95$ \\
\hline Firm Age (in years) & Mean: 9.62; SD ${ }^{1}: 6.70$ \\
\hline $\begin{array}{l}\text { Firms' International Experience } \\
\text { (in years) }\end{array}$ & Mean: $7.43 ; \mathrm{SD}^{1}: 2.89$ \\
\hline $\begin{array}{l}\text { FSTS }^{2} \text { (Foreign Sales/Total Sales } \\
\text { in 2009) (in \%) }\end{array}$ & Mean: $72.01 ; \mathrm{SD}^{1}: 28.40$ \\
\hline $\begin{array}{l}\text { FSTS }{ }^{2} \text { Three Years after } \\
\text { Company Establishment (in \%) }\end{array}$ & Mean: 71.60; $\mathrm{SD}^{1}: 25.01$ \\
\hline $\begin{array}{l}\text { Time from Company } \\
\text { Establishment to Initial } \\
\text { Internationalisation (in years) }\end{array}$ & Mean: $0.74 ; \mathrm{SD}^{1}: 1.00$ \\
\hline Foreign Market Entry Mode & $\begin{array}{l}\text { Exporting }(69.5 \%) \text {, Wholly-owned sales subsidiary } \\
(8.2 \%) \text {, Strategic alliance }(6.6 \%) \text {, Joint venture }(4.1 \%) \text {, } \\
\text { Licensing }(3.1 \%) \text {, Wholly-owned manufacturing } \\
\text { subsidiary }(0.6 \%) \text {, Franchising }(0.6 \%) \text {, Other }(7.2 \%)\end{array}$ \\
\hline $\begin{array}{l}\text { Initial International Markets } \\
\text { (NB: the total percentage is } \\
\text { above } 100 \% \text { as some sample } \\
\text { firms entered several } \\
\text { international markets } \\
\text { simultaneously) }\end{array}$ & $\begin{array}{l}\text { USA (53.7\%), Australia/New Zealand (49.0), UK } \\
\text { (37.4\%), Japan (19.0\%), Singapore (16.3\%), China } \\
(15.0 \%) \text {, Germany (12.2\%), South Korea (8.8\%), } \\
\text { Thailand (7.5\%), Indonesia (6.8\%), Malaysia (6.1\%), } \\
\text { India (5.4\%), Netherlands (5.4\%), Taiwan (4.8\%), } \\
\text { Canada (4.1\%), Hong Kong (4.1\%), South Africa }(3.4 \%)\end{array}$ \\
\hline Industry Sector & $\begin{array}{l}\text { Manufacturing (27.2\%), Services (38.8\%), Others (e.g., } \\
\text { Agriculture) }(34.0 \%)\end{array}$ \\
\hline
\end{tabular}

${ }^{1}$ SD: Standard deviation

${ }^{2}$ FSTS: Foreign sales/total sales. 
Table 2 Correlations and discriminant validity of the measurement model

\begin{tabular}{lllll}
\hline & $\mathbf{1}$ & $\mathbf{2}$ & $\mathbf{3}$ & $\mathbf{4}$ \\
\hline 1. Niche orientation & $\mathbf{0 . 7 2 7}$ & & \\
2. Network resources & 0.143 & $\mathbf{0 . 8 4 7}$ & & \\
3. Learning orientation & 0.364 & 0.240 & $\mathbf{0 . 8 0 3}$ & \\
4. Post-entry performance & 0.038 & 0.112 & 0.206 & - \\
\hline
\end{tabular}

The values in italics are the square root of the average variance extracted (AVE) and the off-diagonal values are the correlations between the study constructs

Table 3 Measurement model

\begin{tabular}{|c|c|c|c|}
\hline Construct & Mean & SD & $\begin{array}{c}\text { Outer } \\
\text { loadings }\end{array}$ \\
\hline \multicolumn{4}{|l|}{ Niche orientation $(\mathrm{Alpha}=0.852, \mathrm{CR}=0.886, \mathrm{AVE}=0.529)$} \\
\hline \multicolumn{4}{|l|}{ (strongly disagree $=1$, strongly agree $=7)$} \\
\hline $\begin{array}{l}\text { NO1 We emphasize the uniqueness of our product/service in our } \\
\text { international marketing }\end{array}$ & 6.281 & 0.837 & 0.637 \\
\hline $\begin{array}{l}\text { NO2 We are targeting specialized needs in international markets that } \\
\text { competitors find hard to meet }\end{array}$ & 5.952 & 1.178 & 0.743 \\
\hline $\begin{array}{l}\text { NO3 Our product/service represents a new and innovative way of meeting } \\
\text { a demand }\end{array}$ & 5.782 & 1.230 & 0.776 \\
\hline $\begin{array}{l}\text { NO4 Our most important product/service is highly specialized for } \\
\text { international markets }\end{array}$ & 5.336 & 1.590 & 0.777 \\
\hline NO5 Our product/service is unique with respect to technology & 4.925 & 1.688 & 0.738 \\
\hline NO6 Our international strategy is to serve an unmet market needs & 5.163 & 1.684 & 0.726 \\
\hline $\begin{array}{l}\text { NO7 We found a niche in the market and are focused on exploiting it in } \\
\text { international markets }\end{array}$ & 5.803 & 1.327 & 0.685 \\
\hline \multicolumn{4}{|l|}{ Network resources $(\mathrm{Alpha}=0.662, \mathrm{CR}=0.833, \mathrm{AVE}=0.719)$} \\
\hline \multicolumn{4}{|l|}{$($ strongly disagree $=1$, strongly agree $=7)$} \\
\hline $\begin{array}{l}\text { NR1 Personal contacts of our management provided our company with } \\
\text { important networks for internationalization }\end{array}$ & 5.844 & 0.837 & 0.961 \\
\hline $\begin{array}{l}\text { NR2 Our company had a lot of pre-existing personal networks for } \\
\text { internationalization }\end{array}$ & 4.619 & 1.178 & 0.716 \\
\hline \multicolumn{4}{|l|}{ Learning orientation $(\mathrm{Alpha}=0.816, \mathrm{CR}=0.879, \mathrm{AVE}=0.645)$} \\
\hline \multicolumn{4}{|l|}{$($ strongly disagree $=1$, strongly agree $=7)$} \\
\hline $\begin{array}{l}\text { LO1 Our managers basically agree with our company's ability to learn is } \\
\text { the key to our competitive advantage }\end{array}$ & 5.667 & 1.207 & 0.724 \\
\hline $\begin{array}{l}\text { LO2 The basic values of our company include learning as key to } \\
\text { improvement }\end{array}$ & 5.918 & 1.017 & 0.813 \\
\hline $\begin{array}{l}\mathrm{LO} 3 \text { The sense around here is that employee learning is an investment, not } \\
\text { an expense }\end{array}$ & 5.789 & 1.099 & 0.804 \\
\hline $\begin{array}{l}\text { LO4 Learning in our organization is seen as a key commodity necessary to } \\
\text { guarantee the survival of our company. }\end{array}$ & 5.871 & 0.988 & 0.866 \\
\hline \multicolumn{4}{|l|}{ Post-entry performance - second-order construct } \\
\hline OP Operational performance & - & - & 0.944 \\
\hline FP Financial performance & - & - & 0.937 \\
\hline OE Overall effectiveness & - & - & 0.942 \\
\hline
\end{tabular}




\begin{tabular}{|c|c|c|c|}
\hline Operational performance & & & \\
\hline $\begin{array}{l}\text { Relative to prior expectations, how satisfied were you with your company's } \\
\text { main international business for the first five year's initial international } \\
\text { business activity? }\end{array}$ & & & \\
\hline OP1 Market share in international markets & 4.603 & 1.472 & - \\
\hline OP2 International reputation of the firm & 5.468 & 1.225 & - \\
\hline OP3 New product/service introduction in international markets & 5.039 & 1.250 & - \\
\hline OP4 Presence in strategically located countries worldwide & 4.759 & 1.439 & - \\
\hline OP5 Time to market for new product/services internationally & 4.747 & 1.472 & - \\
\hline OP6 Gaining a foothold in international markets & 5.063 & 1.526 & - \\
\hline OP7 Number of successful new products/services in international markets & 4.831 & 1.327 & - \\
\hline Financial performance & & & \\
\hline $\begin{array}{l}\text { Relative to prior expectations, how satisfied were you with your company's } \\
\text { main international business for the first five year's initial international } \\
\text { business activity? } \\
\text { (not satisfied at all=1, extremely satisfied=7) }\end{array}$ & & & \\
\hline FP1 International sales volume & 5.304 & 1.540 & - \\
\hline FP2 International sales growth & 5.231 & 1.577 & - \\
\hline FP3 International profitability & 5.165 & 1.536 & - \\
\hline FP4 Return on investment from international business & 4.978 & 1.547 & - \\
\hline Overall effectiveness & & & \\
\hline $\begin{array}{l}\text { How would you rate the success of your company's main international } \\
\text { business for the first five years after your company's initial international } \\
\text { business activity? }\end{array}$ & & & \\
\hline OE1 International business success & 5.316 & 1.251 & - \\
\hline OE2 International business success compared to main competitors & 5.076 & 1.427 & - \\
\hline $\begin{array}{l}\text { Relative to prior expectations, how satisfied were you with your company's } \\
\text { main international business for the first five year's initial international } \\
\text { business activity? }\end{array}$ & & & \\
\hline $\begin{array}{l}\text { (not satisfied at all }=1 \text {, extremely satisfied }=7 \text { ) } \\
\text { OE3 Overall international business performance }\end{array}$ & 5.128 & 1.449 & - \\
\hline
\end{tabular}


Figure 1 Hypothesis test results

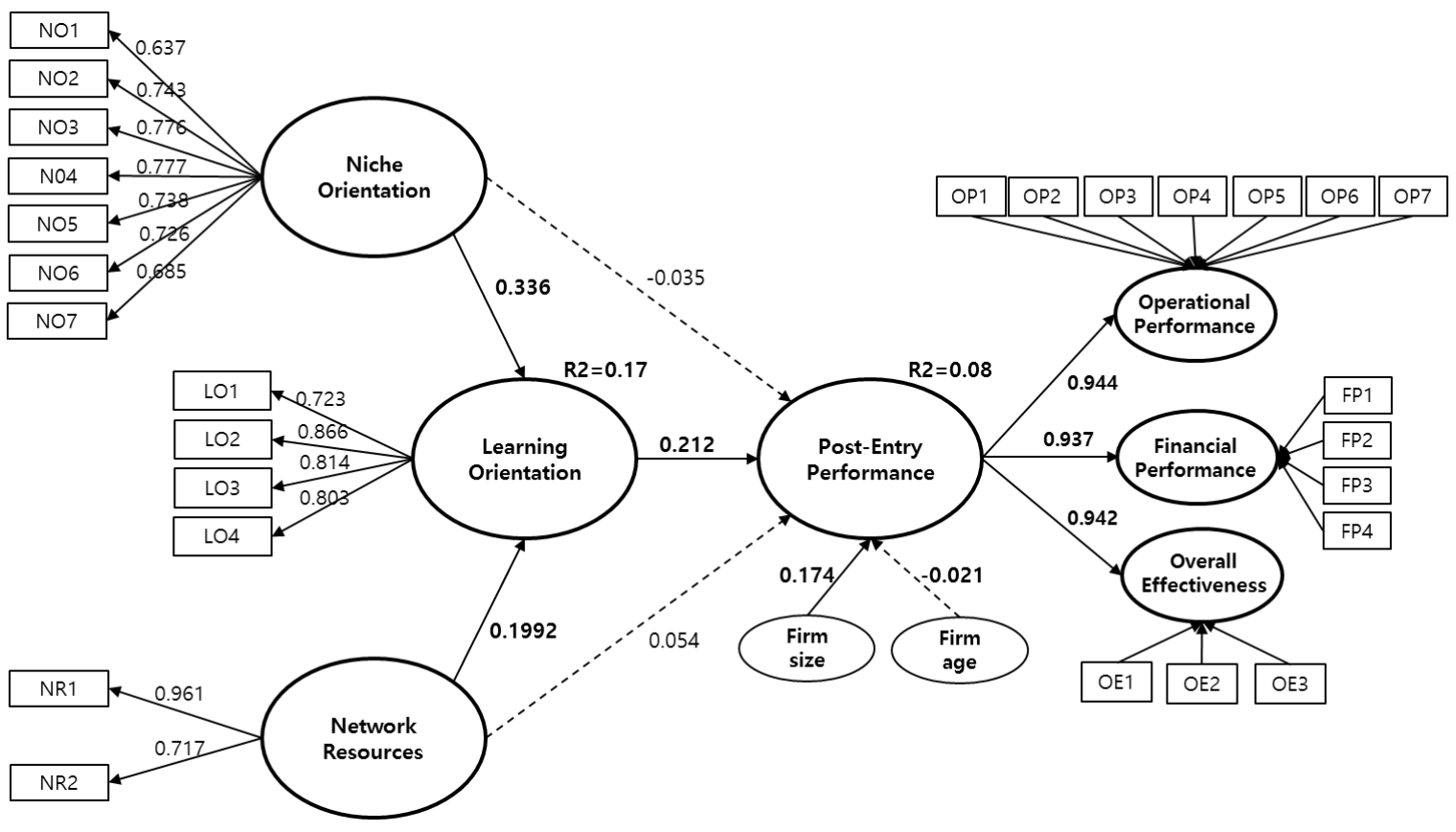

